\title{
Is remote and distance teaching during the COVID-19 pandemic related to the university professors' weight gain, body mass index changes, hearing complaints, and self-perception of voice?
}

\author{
Luciana Lozza de Moraes Marchiori ${ }^{1,2}$ \\ https://orcid.org/0000-0002-9026-0468 \\ Glória de Moraes Marchiori, ${ }^{1,2,3}$ \\ https://orcid.org/0000-0002-2987-1665 \\ Matheus Lindofer Rodrigues ${ }^{1,2,3}$ \\ https://orcid.org/0000-0002-7573-619X \\ Priscila Carlos ${ }^{1,2,3}$ \\ https://orcid.org/0000-0003-0622-9597 \\ Nicoli Meurer Cordova ${ }^{1,2,3}$ \\ https://orcid.org/0000-0001-6834-5935 \\ Michelle Cardoso Machado dos Santos ${ }^{1,2}$ \\ https://orcid.org/0000-0003-0516-4576 \\ Braulio Henrique Magnani Branco',2,4 \\ https://orcid.org/0000-0002-4625-9128 \\ Daiane Soares de Almeida Ciquinato ${ }^{2,5}$ \\ https://orcid.org/0000-0002-3280-7218
}

Laboratório Interdisciplinar de Intervenção em Promocão da Saúde. Universidade Cesumar - Unicesumar, Maringá, Paraná, Brasil.

Grupo de Pesquisa em Educação Física, Fisioterapia, Esporte, Nutrição e Desempenho - GEFFEND/Unicesumar), Maringá, Paraná, Brasil.

${ }^{3}$ Universidade Cesumar - Unicesumar, Maringá, Paraná, Brasil.

Universidade Cesumar - Unicesumar, Programa de Pós-Graduação em Promoção da Saúde, Maringá, Paraná, Brasil.

Prefeitura Municipal de Cambé, Departamento de Saúde Ocupacional, Cambé, Paraná, Brasil.

Research support source: Araucaria Foundation; PPSUS - Programa Pesquisa para o SUS; Instituto Cesumar de Ciência, Tecnologia e Inovação. Conflict of interests: Nonexistent

\section{(c) (i)}

Received on: June 6, 2021 Accepted on: October 26, 2021

Corresponding address: Daiane Soares de Almeida Ciquinato Interdisciplinary Health Promotion Intervention Laboratory (LIIPS), Cesumar University

Avenida Guedner, 1610, Aclimação Zipcode: 87.050-900 - Maringá, Paraná, Brazil

E-mail: ciquinato19@gmail.com

\section{ABSTRACT}

Purpose: to verify the impact of weight and BMI (Body Mass Index) changes on auditory and vocal symptoms in university professors, during the COVID-19 pandemic.

Methods: the symptoms were assessed with a semi-structured questionnaire developed on Google Forms, to which the consent form was appended. It comprised 27 questions related to symptoms, changes, and health, during the pandemic - specifically, vocal and auditory symptoms, anthropometric factors, vocal parameters, physical activity, neck pain, and comorbidities. The Mann-Whitney and Chi-square test were used to identify differences or associations between variables (95\% Cl; $\mathrm{P}<0.05)$.

Results: altogether, 74 professors who comprise the faculty of the undergraduate program at the institution where the research was conducted were assessed. Significant differences were found between those with auditory symptoms (G1: worsened hearing; G2: unchanged hearing) regarding BMI, in which G1 had higher values; and sleep, in which G1 slept fewer hours. The chi-square test showed an association between the groups and BMI classification - those with worsened hearing (G1) were more overweight and their sleeping hours were more affected. There was also an association between the groups and voice change, headphone use (mainly in-ear) during classes, dizziness or vertigo episodes, tinnitus episodes and headache.

Conclusion: this study revealed an association between worsened hearing, sleep, and BMI in university professors due to remote and distance teaching during the COVID-19 pandemic.

Keywords: Hearing; Voice; Body Mass Index; Faculty; Pandemics, COVID-19 


\section{INTRODUCTION}

Various studies have pointed out that changes in lifestyle habits influence well-being, hearing, and voice. However, there is a lack of studies on the prevalence and probable associations of hearing and voice loss in university professors during the COVID-19 pandemic. At the same time, it is necessary to work on specific health promotion guidelines for the affected population to minimize or remedy the symptoms that result from changes in work practice and the new reality. Teleworking is broadly defined as the use of computers and telecommunications to change the established geography of work. It involves a series of aspects, including the economic, social, cultural, organizational, environmental, and legal ones, to name a few ${ }^{1}$.

As changes in society and advancements of information and communication technology take place, new ways of making working relationships more flexible have spread, including telework. One teleworking modality is that in which the person works from home while maintaining the formal employment relationship with an organization ${ }^{2}$. The COVID-19 pandemic has posed a major challenge to both health and the work process in general; hence, strategies to cope with it must be developed and implemented ${ }^{3}$. University professors, used to face-to-face teaching, had to adapt to teleworking - some of them using computers and headphones more intensely. This need came along with other changes in their lifestyle, imposed by the necessary social distancing. It hindered the habitual physical activities and sleep schedule and brought about changes in nutritional, postural, physical, and mental health - affecting phonation, for instance. Such changes can trigger auditory and vocal symptoms since all of them have effects on both the sensory and motor systems ${ }^{4}$.

This study analyzed the primary stress factors that female online university professors are exposed to. The Delphi method was used in the prospective and exploratory analysis, highlighting mental overload, emotional exhaustion, time pressure, and lack of schedule. These risk factors are related to the increasing use of information and communication technology and to the university system itself - as professors are expected to develop both research and the necessary intervention programs to improve and protect their health from stress and other psychosocial risks ${ }^{5}$, which may be associated with the teacher's lifestyle in relation to their nutrition, bedtime and BMI (Body Mass Index) ${ }^{5}$. A high $\mathrm{BMI}$ with a prevalence of overweight/obesity is a trend observed in different populations, including teachers ${ }^{6}$. A recent study shows the impact of BMl alterations on tinnitus auditory symptoms among teachers ${ }^{7}$. In addition, the study seeks to understand the influence of $\mathrm{BMI}$, on acoustic parameters and symptoms of voice, and BMI can be influencing the average fundamental frequency of overweight and obese individuals ${ }^{8}$. The reduction in lung function due to increased adipose tissue around the ribs and abdomen drives to reduced chest compliance and respiratory muscle strength capacity. This is based on the fact that overweight increases tissue mass in the neck, chest and upper airways, particularly the laryn $x^{8}, 9$ and can influence vocal production and auditory symptoms, increasing the isolation in which the teachers find themselves.

Thus, the present study aimed to verify the impact of weight and BMI changes on auditory and vocal symptoms in university professors during the COVID-19 pandemic.

\section{METHODS}

This cross-sectional study is an integral part of broader research. The project was approved by the Human Research Ethics Committee at the University Center of Maringa, Brazil (CEP: 3.585.917), and all the patients were previously informed about its purpose and procedures and signed the informed consent form. The inclusion criteria encompassed being undergraduate professors at the institution of origin, currently teaching, who had not taken a leave of absence longer than 30 days in the previous 12 months. The exclusion criterion was their unavailability to fully answer the questionnaire and pregnancy.

The auditory symptoms and weight gain were assessed with a self-administered and semi-structured questionnaire developed on Google Forms, to which the consent form was appended. The professors were aware of the study aims. The questionnaire was distributed among institutional media groups comprising university professors, with identifying data of the participants. To get the highest possible response rate, another two reminders were sent to the professors during one month.

The survey included it comprised 27 questions related to symptoms, changes, and health during the pandemic - specifically, voice and auditory symptoms, anthropometric factors, sleep parameters, physical activity, neck pain, and comorbidities. The questionnaire also covered professor participants' basic, such as their age, gender, as well as questions about 
electronic resources, changes to work, and in nutritional, postural, physical, and mental health during the COVID-19 pandemic. After data collection, participants were divided into two groups based on their hearing complaints (G1: worsened hearing; G2: unchanged hearing) and voice complaints (G1: worsened voice; G2: unchanged voice).

\section{Statistical analysis:}

The statistical power of the sample was calculated with a post hoc test in the GPower 3.1.7 software, using the mean BMI and standard deviation for $\mathrm{G} 1$ ( $n=15$ participants; $29.7 \pm 7.2)$ and $\mathrm{G} 2(\mathrm{n}=59$ participants; $25.3 \pm 3.6)$ regarding auditory symptoms. It demonstrated a moderate effect size at 0.77 , with a $75 \%$ power and $a=0.05$.

The statistical data analysis was conducted with the Statistical Package for the Social Sciences, version 20.0 (SPSS, UK), with a 95\% Cl and 5\% significance level $(P<0.05)$ in all the tests. The parametric distribution of the data was verified with the Shapiro-Wilk test with no assumption of normality, whereas the Mann-Whitney test was used for continuous variables. The Mann-Whitney effect size was also calculated with the following equation: $r=Z / \sqrt{ }$, in which " $r$ " is the correlation coefficient, " $Z$ " is the standardized U-value, and " $n$ " is the number of observations. The interpretation of the r-value and Pearson's correlation coefficient $(r)$ coincide $(16,17)$. The association with categorical variables was analyzed with the Chi-square test. The Phi and Cramer's V were also calculated.

\section{RESULTS}

Altogether, 74 professors who comprise the faculty of the undergraduate program at the institution where the research was conducted were assessed. Their mean age was $42.1 \pm 8.9$ years; $68.9 \%(N=51)$ were females and $31.1 \%(\mathrm{~N}=23)$ were males; $47.3 \%$ were well-nourished $(\mathrm{N}=35)$ and $16.2 \%(\mathrm{~N}=12)$ were obese; 20.3\% ( $n=15)$ reported worsened hearing due to remote classes and $44.6 \%(n=33)$ reported worsened sleep. The descriptive data of the sample are shown in Table 1.

No significant results $(P>0.05)$ were found between the groups with speech symptoms. On the other hand, significant differences were found between those with auditory symptoms (G1: worsened hearing; G2: unchanged hearing) regarding $B M I(P=$ 0.007), in which $G 1$ had higher values; and sleep ( $P$
Table 1. Descriptive data of the sample $(N=74)$

\begin{tabular}{lc}
\hline GENERAL CHARACTERISTICS & \\
\hline Gender & $\mathrm{N}=51(68.9 \%)$ \\
Female & $\mathrm{N}=23(31.1 \%)$ \\
Male & $\mathrm{N}=38(51.4 \%)$ \\
\hline Age range (years) & $\mathrm{N}=36(48.6 \%)$ \\
$25-40$ years & $42.1 \pm 8.9$ \\
$41-71$ years & \\
Mean \pm standard deviation & $\mathrm{N}=2(2.7 \%)$ \\
\hline Weekly workload & $\mathrm{N}=7(9.5 \%)$ \\
Up to 20 hours & $\mathrm{N}=32(43.2 \%)$ \\
24 hours & $\mathrm{N}=33(44.6 \%)$ \\
40 hours & $73[21] \mathrm{a}$ \\
Per hour & $1.67[10]$ \\
\hline Weight (Kg) & $25.6[5.3]$ \\
Height (m) & \\
BMI & $\mathrm{N}=35(47.3 \%)$ \\
\hline BMI (classification) & $\mathrm{N}=27(36.5 \%)$ \\
Eutrophic (18.50 at 24.99) & $\mathrm{N}=12(16.2 \%)$ \\
\hline Overweight (25.00 at 29.99) &
\end{tabular}

Was there any change in your level of physical activity?

No change

Yes, decreased

Yes, stopped

Yes, increased

$\mathrm{N}=27(36.5 \%)$

$\mathrm{N}=29(39.2 \%)$

$\mathrm{N}=13(17.6 \%)$

Were there any changes in your sleep?

No changes

$\mathrm{N}=5(6.8 \%)$

Yes, it got worse

Yes, it got better

$\mathrm{N}=36(48.6 \%)$

$\mathrm{N}=33(44.6 \%)$

$\mathrm{N}=5(6.8 \%)$

How many hours on average, without

a break, have you spent in front of the

computer?

Up to 3 hours $\quad \mathrm{N}=18(24.3 \%)$

Up to 4 hours $\quad \mathrm{N}=14(18.9 \%)$

More than 5 hours

$\mathrm{N}=42(56.8 \%)$

With the remote classes, did you feel

any change in your voice?

No changes

$\mathrm{N}=44(59.5 \%)$

Yes, it got worse

$\mathrm{N}=23(31.1 \%)$

Yes, it got better

$\mathrm{N}=7(9.5 \%)$

With the remote classes, did you feel

any changes in your hearing?

No changes $\quad N=59(79.7 \%)$

Yes, it got worse

$\mathrm{N}=15(20.3 \%)$

Do you use headphones during online

classes?

No $\quad \mathrm{N}=36(48.6 \%)$

Yes, in-ear $\quad \mathrm{N}=33(44.6 \%)$

Yes, extra headset $\quad \mathrm{N}=5(6.8 \%)$

a [median and interquartile range]; Kg (Kilogram); m (meter); BMI (Body Mass Index) 
$=0.008$ ), in which G1 slept fewer hours. These tests had a small effect size. The chi-square test showed an association between the groups and BMI classification $(P=0.007)$ - those with worsened hearing (G1) were more overweight, their sleep hours were more affected, and their Mann-Whitney test results were worse. There was also an association between the groups and voice change $(P=0.004)$, headphone use (mainly in-ear) during classes $(P=0.022)$, dizziness or vertigo episodes ( $P=0.001)$, tinnitus episodes $(P=0.003)$, and headache $(P=0.001)$. These data are presented in Table 2.

Table 2. Comparative analyses between $\mathrm{G} 1$ (hearing worsening) and $\mathrm{G} 2$ (no changes in hearing) ( $\mathrm{N}=74$ )

\begin{tabular}{|c|c|c|c|c|}
\hline Continuous Variables & & $\begin{array}{c}G 1 \\
(N=15)\end{array}$ & $\begin{array}{c}\mathrm{G} 2 \\
(\mathrm{~N}=59)\end{array}$ & $\begin{array}{c}\mathbf{P} \\
\text { Mann-Whiney test }\end{array}$ \\
\hline Age (years) & & 39 [34-50]a & $41[35-48]$ & $P=0.692$ \\
\hline Weight $(\mathrm{Kg})$ & & 76 [67-90] & $71[60-80]$ & $P=0.091$ \\
\hline Height (m) & & 1.63 [1.61-1.68] & $1.68[1.63-1.74]$ & $\begin{array}{c}P=0.036^{\star} \\
Z=-2.095 \\
r=0.2 b\end{array}$ \\
\hline BMI & & 27.7 [25.6-32.8] & $24.8[22.5-27.7]$ & $\begin{array}{c}P=0.007^{*} \\
Z=-2.676 \\
r=0.3 b\end{array}$ \\
\hline $\begin{array}{l}\text { Weekly physical activity } \\
\text { (days per week) }\end{array}$ & & $2[0-2]$ & $2[0-3]$ & $P=0.955$ \\
\hline Sleep hours & & $6[5-6]$ & $7[6-7]$ & $\begin{array}{c}P=0.008^{\star} \\
Z=-2.661 \\
r=0.3 b\end{array}$ \\
\hline $\begin{array}{l}\text { Amount of weight you } \\
\text { gained (kilos) }\end{array}$ & & 4 [3-6] & 3 [2-5] & $P=0.261$ \\
\hline $\begin{array}{l}\text { Amount of weight you } \\
\text { lost } 2 \text { (kilos) }\end{array}$ & & $4[3-10]$ & $6[3-11]$ & $P=1.000$ \\
\hline $\begin{array}{l}\text { Time in front of a } \\
\text { computer (hours) }\end{array}$ & & $5[4-5]$ & $5[3-5]$ & $P=0.130$ \\
\hline Categorical Variables & & $\mathrm{N}(\%)$ & N (\%) & $\begin{array}{c}\mathbf{P} \\
\text { Chi-Square test }\end{array}$ \\
\hline Gender & $\begin{array}{l}\text { Female } \\
\text { Male }\end{array}$ & $\begin{array}{c}10(66.7) \\
5(33.3)\end{array}$ & $\begin{array}{l}41(69.5) \\
18(30.5)\end{array}$ & $P=1.000$ \\
\hline Age range (years) & $\begin{array}{l}25-40 \\
41-71\end{array}$ & $\begin{array}{l}9(60) \\
6(40)\end{array}$ & $\begin{array}{l}29(49.2) \\
30(50.8)\end{array}$ & $P=0.567$ \\
\hline BMI (classification) & $\begin{array}{l}\text { Eutrophic } \\
\text { Overweight } \\
\text { Obesity }\end{array}$ & $\begin{array}{c}2(13.3) \\
9(60) \\
4(26.7)\end{array}$ & $\begin{array}{c}33(55.9) \\
18(30.5) \\
8(13.6)\end{array}$ & $\begin{array}{l}P=0.007^{\star} \\
X 2=9.310 \\
V=0.343\end{array}$ \\
\hline $\begin{array}{l}\text { Was there any change } \\
\text { in your level of physical } \\
\text { activity? }\end{array}$ & $\begin{array}{c}\text { No change } \\
\text { Yes, decreased } \\
\text { Yes, stopped } \\
\text { Yes, increased }\end{array}$ & $\begin{array}{c}3(20) \\
8(53.3) \\
3(20) \\
1(6.7) \\
\end{array}$ & $\begin{array}{c}24(40.7) \\
21(35.6) \\
10(16.9) \\
4(6.8) \\
\end{array}$ & $P=0.429$ \\
\hline $\begin{array}{l}\text { Were there any changes } \\
\text { in your sleep? }\end{array}$ & $\begin{array}{l}\text { No changes } \\
\text { Yes, it got worse } \\
\text { Yes, it got better }\end{array}$ & $\begin{array}{c}3(20) \\
11(73.3) \\
1(6.7)\end{array}$ & $\begin{array}{c}33(55.9) \\
22(37.3) \\
4(6.8)\end{array}$ & $\begin{array}{c}P=0.030^{\star} \\
X 2=6.736 \\
V=0.300\end{array}$ \\
\hline $\begin{array}{l}\text { How many hours on } \\
\text { average, without a break, } \\
\text { have you spent in front } \\
\text { of the computer? }\end{array}$ & $\begin{array}{l}\text { Up to } 3 \text { hours } \\
\text { Up to } 4 \text { hours } \\
\text { More than } 5 \text { hours }\end{array}$ & $\begin{array}{c}1(6.7) \\
3(20) \\
11(73.3)\end{array}$ & $\begin{array}{l}17(28.8) \\
11(18.6) \\
31(52.5)\end{array}$ & $P=0.179$ \\
\hline
\end{tabular}




\begin{tabular}{lcccc}
\hline Categorical Variables & & N (\%) & N (\%) & $\begin{array}{c}\text { P } \\
\text { Chi-Square test }\end{array}$ \\
\hline \multirow{2}{*}{$\begin{array}{l}\text { Did you feel any change } \\
\text { in your voice? }\end{array}$} & No changes & $4(26.7)$ & $40(67.8)$ & $\mathrm{P}=0.004^{*}$ \\
& Yes, it got worse & $10(66.7)$ & $13(22)$ & $\mathrm{X} 2=10.258$ \\
Do you use headphones & No it got better & $1(6.7)$ & $6(10.2)$ & $\mathrm{V}=0.389$ \\
during online classes? & Yes, in-ear & $3(20)$ & $33(55.9)$ & $\mathrm{P}=0.022^{*}$ \\
\hline Did you experience & Yes, extra headset & $2(10(66.7)$ & $23(39)$ & $\mathrm{X} 2=6.825$ \\
dizziness or vertigo? & Yes & $7(46.7)$ & $3(5.1)$ & $\mathrm{V}=0.295$ \\
\hline Did you experience & No & $8(53.3)$ & $3(5.1)$ & $\mathrm{P}=0.001^{*}$ \\
tinnitus? & Yes & $6(40)$ & $56(94.9)$ & $\mathrm{X} 2=14.314$ \\
\hline Did you experience & No & $9(60)$ & $4(6.8)$ & $\mathrm{Phi}=0.489$ \\
headaches? & Yes & $14(93.3)$ & $55(93.2)$ & $\mathrm{X} 2=0.003^{*}$ \\
\hline Hypertension & No & $1(6.7)$ & $27(45.8)$ & $\mathrm{Phi}=0.3929$ \\
\hline
\end{tabular}

a [median and interquartile range 25-75\%]; *(statistically significant ); b (effect size); BMl (body mass index, $\mathrm{Kg} / \mathrm{m}^{2}$ )

Caption: $\mathrm{BMI}=$ Body Mass Index

\section{DISCUSSION}

The purpose of this investigation was to verify the impact of weight and BMl changes on auditory and vocal symptoms in university professors during the COVID-19 pandemic. Differences were found between the groups regarding auditory symptoms, BMI (with higher values for G1), and sleep (with fewer sleep hours for G1). An association was found between the groups and BMI classification - those with worsened hearing (G1) were more overweight, their sleep hours were more affected, and their Mann-Whitney test results were worse. There was also an association between the groups and voice change; headphone use (mainly in-ear) during classes; dizziness, vertigo, and tinnitus episodes, and headache. Causality cannot be inferred from these present analyses, because an etiological study was not intended, but rather to descriptively characterize teachers with auditory vocal and auditory symptoms in relation to BMI. However, various factors can be auditory complaints in this population during the COVID-19 pandemic.

Some studies have associated changes in weight with changes in hearing. The Brazilian people had the highest weight gain rate during the pandemic ${ }^{10,11}$. The study by Pascoto et al. ${ }^{12}$ mentions that an abrupt decrease in adipocytes in the Eustachian tube region due to a sharp weight loss might lead to tube support failure and relaxation. Hence, it may ultimately lead to extremely unpleasant symptoms of Eustachian tube dysfunction, such as autophony, cacophony, and aural fullness. Another study states that obesity (i.e., high BMI and large waist circumference) and reduced physical activity are also related to hearing loss. The available results suggest that the nutritional status plays an important role in the maintenance of the auditory capacity ${ }^{13}$. Caloric restriction may be an interesting option to avoid hearing loss, as suggested by results obtained in animal models - although extensive human studies are needed to verify this possibility ${ }^{14}$. In the present study, this relationship was not found which may be due to the few university professors with hearing complaints in this preliminary study.

A high BMI is a trend observed in different populations, including professors. In this study, the prevalence of overweight/obesity was $52.7 \%$. A cross-sectional study ${ }^{15}$ aimed to assess the prevalence of overweight/ obesity and its association with sociodemographic, occupational, and lifestyle factors in 300 public school teachers. In conclusion, only their sex and the consumption of fruits and vegetables remained significantly associated with overweight/obesity among teachers. These findings call for a debate on the need for encouraging teachers and professors to have an active lifestyle. Based on the results of that research 
and the present one, there is a need for guidelines encouraging university professors to minimize weight gain during the pandemic - as the present study showed that most of them gained weight in this period.

This study also found a relationship between worsened hearing (G1) and sleep hours. Sleep plays a fundamental role in mental and physical health, and adequate sleep time and quality are essential for coping with major life events such as the COVID-19 pandemic ${ }^{16}$. Moreover, sleep is known to have a complex, reciprocal relationship with the auditory system ${ }^{17}$. Clarke $(2019)^{18}$ demonstrated in a recent review the existing associations between sleep and both impaired hearing and tinnitus. Sleep has also proved to be associated with dizziness/vertigo episodes in teachers ${ }^{19}$. Therefore, sleep changes should be considered when treating people with hearing symptoms.

Another study aimed to analyze the vocal selfperception of Brazilian teachers and their communication needs, vocal signs and symptoms, and voice-related lifestyles during the coronavirus disease (COVID-19) pandemic and, based on this information, to develop guidance materials intended for dissemination to these teachers and the general community. Although teachers generally noticed voice improvements during the pandemic, a proportion of them perceived worsening of voices. Many indicated several factors in which speech-language pathologists could guide them to improve performance and comfort during remote and hybrid classes, an initiative that will positively impact not only their voice and communication but also their quality of life ${ }^{20}$. Thus, additional studies should be developed to confirm these findings. These observations corroborate the diagnosis of speech and auditory symptoms in professors, especially regarding their lifestyle and comorbidity patterns due to remote and distance teaching during the COVID-19 pandemic ${ }^{20}$.

At the individual level, teleworking specifically involves space-time issues and professional-personal conflicts regarding their values and demands, besides the isolation in which they find themselves ${ }^{1}$. One teleworking modality is that in which the person works from home while maintaining the formal employment relationship with an organization ${ }^{2}$. The COVID-19 crisis shows how companies have used teleworking to ensure their employees' safety while continuing their economic activity. The results of this study reinforce the relevance of safety factors in the study of teleworking and should be considered in future research ${ }^{21}$ - which should approach the quality of life of professors, not only in general but particularly of those who have voice and hearing complaints. Thus, strategies can be created to reduce the possible symptoms and comorbidities arising from remote and distance teaching during the COVID-19 pandemic. Also, other studies should be conducted aiming to analyze BMl and these auditory and voice symptoms in relation to remote and hybrid classes during the COVID-19 pandemic .

This cross-sectional study has some limitations. While its results allow associations between some variables, no causal relationships could be established between weight gain, self-perception of voice, and hearing complaints because of the small number of participants in each group. Of the 400 professors at the university campus, only 75 answered the questionnaire - one of whom was excluded from the research because she was pregnant at the time. The little adherence may be explained by the many new challenges and activities these professors were subject to during the pandemic. Another limitation was that weight gain, voice changes, and hearing complaints were self-reported, as well as the other variables. It can be stated, in contrast, that professors have a high schooling level and fully answered the questionnaire. Also, few participating professors had voice complaints.

\section{CONCLUSION}

This study revealed an association between worsened hearing, sleep, and BMI in university professors due to remote and distance teaching during the COVID-19 pandemic. These conditions must be assessed in the post-pandemic period as well. The results of this research are expected to encourage further investigation to determine the association between hearing loss, voice changes, and anthropometric factors in university professors. Such studies could be the basis for early interventions to prevent and minimize the effects of obesity and overweight and avoid problems related to their quality of life.

\section{REFERENCES}

1. Sakuda LO, Vasconcelos FC. Teletrabalho: desafios e perspectivas. Organ Soc. 2005;12(33):39-49.

2. Barros AM, Silva JRG. Percepções dos indivíduos sobre as consequências do teletrabalho na configuração home-office: estudo de caso na Shell Brasil. Cad. EBAPE.BR. 2010;8(1):71-91.

3. Fillis MMA, Dellaroza MSG, Machado RA, Pelaquim TAA, Coelho V, Barbosa VCAA et al. Saúde do 
trabalhador em tempos de COVID-19: a experiência do município de Londrina. APS em Revista. 2020;2(2):106-13.

4. Mann L, Kleinpaul JF, Mota CB, Santos SG. Equilíbrio corporal e exercícios físicos: uma revisão sistemática. Motriz. 2009;15(3):713-22.

5. García-González MA, Torrano F, García-González G. Analysis of stress factors for female professors at online universities. Int $\mathrm{J}$ Environ Res Public Health. 2020;24;17(8):2958.

6. Rocha SV, Cardoso JP, Santos CA, Munaro HLR, Vasconcelos LRC, Petroski EL. Overweight/obesity in teachers: prevalence and associated factors. Rev Bras Cineantropom Desempenho Hum. 2015;17(4):450-9.

7. Marchiori LLM, Marchiori GM, Carlos P, Benites SL, Mendes MSB, Ciquinato DSA. Do Body Mass Index levels correlate with tinnitus among teachers? Int Arch Otorhinolaryngol. 2021. DOI: 10.1055/s-0040-1722251

8. Souza LBR, Santos MMD. Body mass index and acoustic voice parameters: Is there a relationship? Braz J Otorhinolaryngol. 2018;84(4):410-5.

9. Salomon NP, Helou LB, Dietrich-Burns K, Stojadinovic A. Do obesity and weight loss affect vocal function? Semin Speech Lang. 2011;32(1):31-42.

10. Bailey P, Purcell S, Calvar J, Baverstock A. Diet and health under COVID-19. [paper on the internet]. 2021. [acess in Feb 18 2021]. Available at: https://www.ipsos.com/sites/default/files/ct/news/ documents/2021-01/diet-and-health-undercovid-19.pdf

11. Barsties B, Verfaillie R, Roy N, Maryn Y. Do body mass index and fat volume influence vocal quality, phonatory range, and aerodynamics in females? CoDAS. 2013;25(4):310-8.

12. Pascoto G, Abreu C, Silva ML, Weber R, Pignatari SS, Stamm A. Share the impact of acute loss of weight on eustachian tube function. Int Arch Otorhinolaryngol. 2014;18(4):376-9.

13. Emmett SD, West KP Jr. Nutrition and hearing loss: a neglected cause and global health burden. Am. J. Clin. Nutr. 2015;102(5):987-8.

14. Puga AM, Pajares MA, Varela-Moreiras G, Partearroyo T. Interplay between nutrition and hearing loss: state of art. Nutrients. 2018;11(1):1-26.

15. Rocha SV, Cardoso JP, Santos CA, Munaro HLR, Vasconcelos LRC, Petroski EL. Overweight/obesity in teachers: prevalence and associated factors.
Rev. bras. cineantropom. desempenho hum. 2015;17(4):450-9.

16. Morin CM, Carrier J, Bastien C, Godbout R. Canadian sleep and circadian network. Sleep and circadian rhythm in response to the COVID-19 pandemic. Can J Public Health. 2020;111(5):654-7.

17. Velluti RA, Pedemonte M. Sensory neurophysiologic functions participating in active sleep processes. Sleep Science. 2021;5(4):131-8.

18. Clarke NA, Hoare DJ, Killan EC. Evidence for an association between hearing impairment and disrupted sleep: scoping review. Am J Audiol. 2019;28(4):1015-24.

19. Ciquinato DSA, Gibrin PCD, Félix CJL, Bazoni JÁ, Marchiori LLM. Sleep lifestyle correlate of dizziness among teachers. Int Arch Otorhinolaryngol. 2021;25(2):e213-e218.

20. Nemr K, Simões-Zenari M, Almeida VC, Martins GA, Saito IT. COVID-19 and the teacher's voice: self-perception and contributions of speech therapy to voice and communication during the pandemic. Clinics. 2021;76:e2641. DOI: 10.6061/clinics/2021/ e2641.

21. Belzunegui-Eraso A, Erro-Garcés A. Teleworking in the context of the Covid-19 crisis. Sustainability. 2020;12(9):1-18. 